( Н. Н. ВЕЛИГОЦКИЙ, Н. В. ДЕДУХ, В. В. КОМАРЧУК, Е. В. КОМАРЧУК

Харьковская медицинская академия последипломного образования

\title{
Морфологические предпосылки неудовлетворительных результатов оперативного лечения грыж пищеводного отверстия диафрагмы
}

\author{
N. N. VELYHOTSKYI, N. V. DEDUKH, V. V. KOMARCHUK, E. V. KOMARCHUK \\ Kharkiv Medical Academy of Post-Graduate Education
}

\section{MORPHOLOGICAL PRECONDITIONS OF BAD RESULTS OF SURGICAL TREATMENT OF HERNIAS OF ESOPHAGEAL HIATUS}

\begin{abstract}
Проведено исследование мышечной и сухожильной части ножек диафрагмы 34 пациентов с грыжами пищеводного отверстия диафрагмы I-III степени в возрасте 43-58 лет. Обнаружены выраженные структурные нарушения, особенно при грыжах II-III степени, заключающиеся в гиалинизации сухожильной ткани, дегенерации мышечной ткани, наличии лимфогистиоцтарных инфильтратов, венозном застое. Найденные изменения могут способствовать развитию рецидива грыжи при выполнении аутопластики.

Study of muscle and tendon part of the crus of the diaphragm in 34 patients with hiatal hernia I-III degree at the age of 43-58 years was conducted. There were expressed structural damages, especially in hernia II-III degree, consisting of the tendon tissue hyalinization, degeneration of muscle tissue, the presence of combined infiltrates, venous stasis. Found changes may contribute to the development of recurrent hernias after autoplasty.
\end{abstract}

Постановка проблемы и анализ последних исследований и публикаций. Независимо от прогресса хирургической техники грыж, такие проблемы, как рецидивирование, послеоперационные осложнения, связанные с хронической болью и дискомфортом пациента, являются реальностью и нуждаются в углубленном исследовании. Истоки этих проблем, вероятно, связаны с тем, что до сих пор не раскрыты причины грыжеобразования. Биохимические исследования, проведенные в последние годы, позволили предположить, что в грыжеобразовании определенную роль играют особенности формирования и функционирования коллагеновых структур $[1,2,4,6,8]$. Однако в литературе практически отсутствуют данные, основанные на гистологических исследованиях тканей, принимающих участие в грыжеобразовании - мышечной и соединительной ткани.

Цель работы. Изучить структурную организацию мышечной и сухожильной части ножек диафрагмы, края диафрагмы у пациентов с грыжами пищеводного отверстия диафрагмы.

Материалы и методы. Для исследования использовали операционный материал, полученный от 34 пациентов с грыжами пищеводного отверстия диафрагмы. Из них 12 - с грыжами I степе- ни, 13 - с грыжами II степени, 9 - с грыжами III степени. Возраст больных был в пределах 43-58 лет, а стаж грыженосительства составлял от 3 до 16 лет.

Для гистологических исследований операционный материал фиксировали в $10 \%$ растворе нейтрального формалина, обезвоживали в спиртах возрастающей крепости и заключали в парафин [3]. Гистологические срезы изготавливали на санном микротоме "Reichert" толщиной 7-9 мкм и окрашивали гематоксилином и эозином, а также пикрофуксином по Ван Гизон. Окрашенные срезы анализировали и фотографировали (с помощью цифровой фотокамеры Canon EOS-300D) под микроскопом "AxioStar Plus".

Для изучения типов коллагена в поляризованном свете проводилась реакция с сириусом красным. Поляризационный метод, основанный на постановке реакции с пикросириусом красным, относится к селективному гистохимическому методу для изучения типов коллагена и их деградации [7, 9]. При исследовании срезов в поляризационном микроскопе слабая рефракция коллагеновых волокон или отсутствие рефракции на участках отражает их молекулярную дезорганизацию вследствие коллагенолиза. Зрелые формы коллагена I типа светятся в поляризован- 
ном свете красным цветом, коллаген III типа зеленым цветом.

Результаты исследований и их обсуждение. При грыжах пищеводного отверстия диафрагмы изменения обнаружены как в мышечной, так и в сухожильной тканях ножки диафрагмы. В мышечной ткани выявляются обширные участки деструктивных и дистрофических нарушений (рис. 1). Мышечные волокна истончены, не формируют синцитеподобной структуры, характерной для мышечной ткани. Обнаруживается их распад на фрагменты. Плотность мышечных ядер низкая, между мышечными волокнами они распределены неравномерно, при этом на отдельных участках выявлены их скопления. Обнаруживаются обширные очаги гомогенизации мышечных волокон. Между неупорядоченно расположенными мышечными волокнами формируются поля жировой ткани. Сосуды в области мышечной ткани переполнены кровью или облитерированы.

В сухожильной ткани ножки диафрагмы обнаруживаются пучки коллагеновых волокон без четкой ориентации, имеет место их фрагментация. На участках вместо плотной соединительной ткани, характерной для сухожилия, присутствует рыхлая соединительная ткань с неоформленным межклеточным веществом (рис. 2).

Обнаруживаются очаги периваскулярной клеточной инфильтрации лимфоцитами и макрофагами, а также переполнение кровью сосудов (стаз) (рис. 3).

Структура тканей в области края диафрагмы нарушена. Межклеточное вещество соединительной ткани на участках представлено в основном коллагеновыми волокнами, с выраженной оссификацией и гиалинизацией (рис. 4).

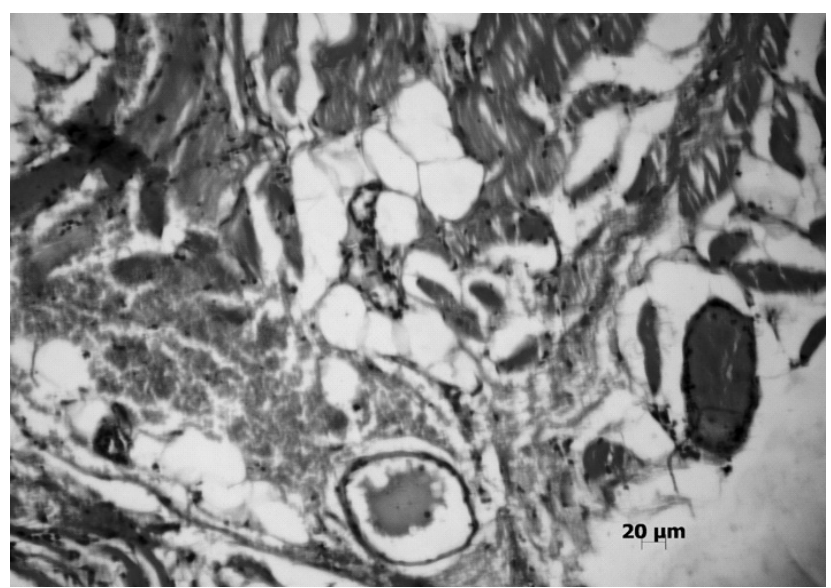

Рис. 1. Мышечная ткань ножки диафрагмы. Очаги гомогенизации мышечных волокон. Распад мышечных волокон на фрагменты. Низкая плотность мышечных ядер. Очаги жировой ткани. Сосуды переполнены кровью или облитерированы. Гематоксилин и эозин. Ув. 200.
Обнаруживаются очаги неоформленной бесструктурной соединительной ткани с обширными очагами лизиса и низкой плотностью клеток (рис. 5).

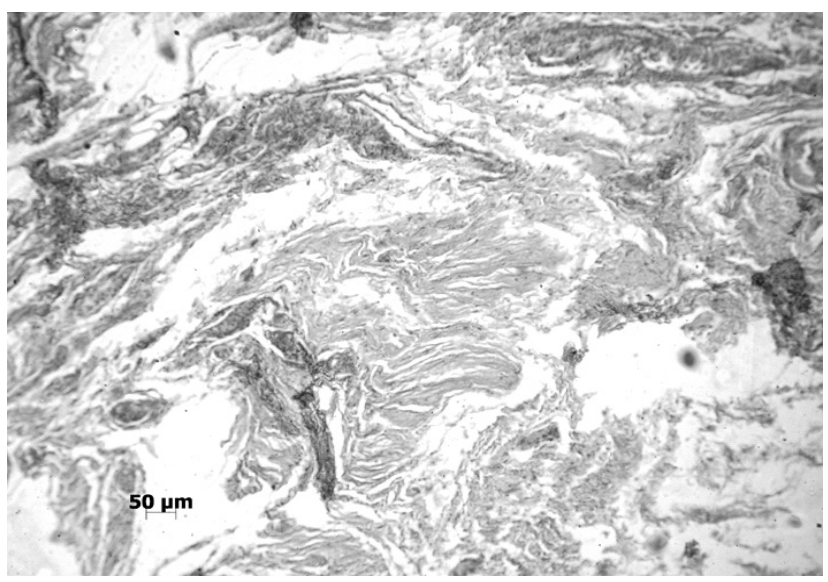

Рис. 2. Сухожильная ткань ножки диафрагмы. Рыхлая соединительная ткань с неоформленным межклеточным веществом. Гематоксилин и эозин. Ув. 50.

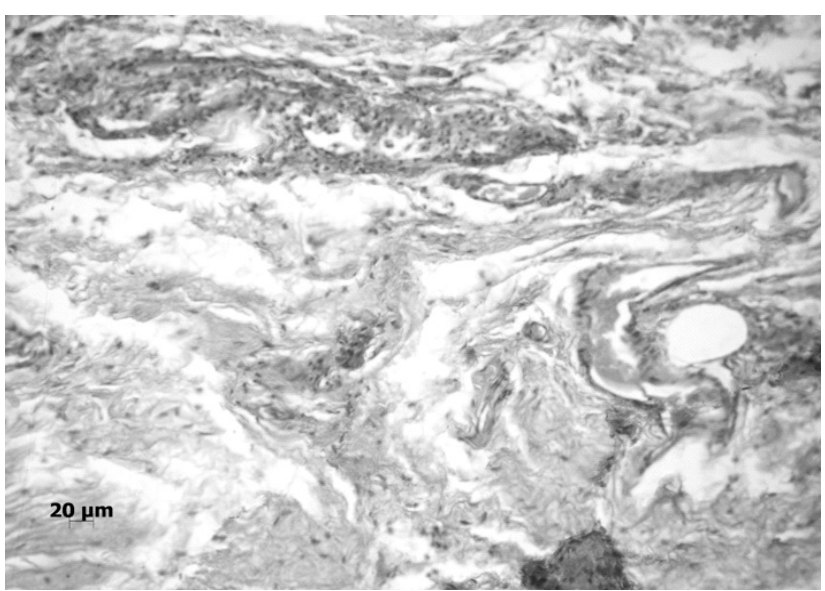

Рис. 3. Очаги периваскулярной клеточной инфильтрации. Стаз сосудов. Гематоксилин и эозин. Ув. 200.

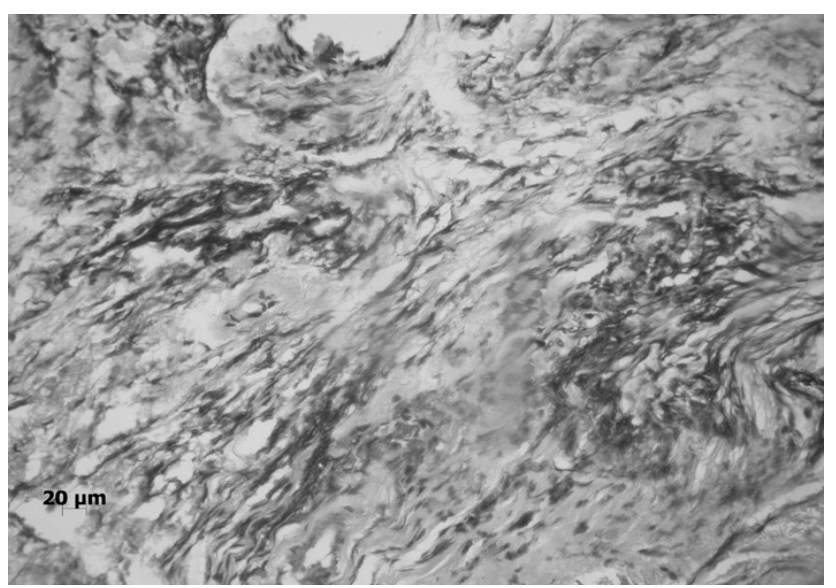

Рис. 4. Край диафрагмы. Обширные очаги гиалинизации и оссификация соединительной ткани. Гематоксилин и эозин. Ув. 200. 


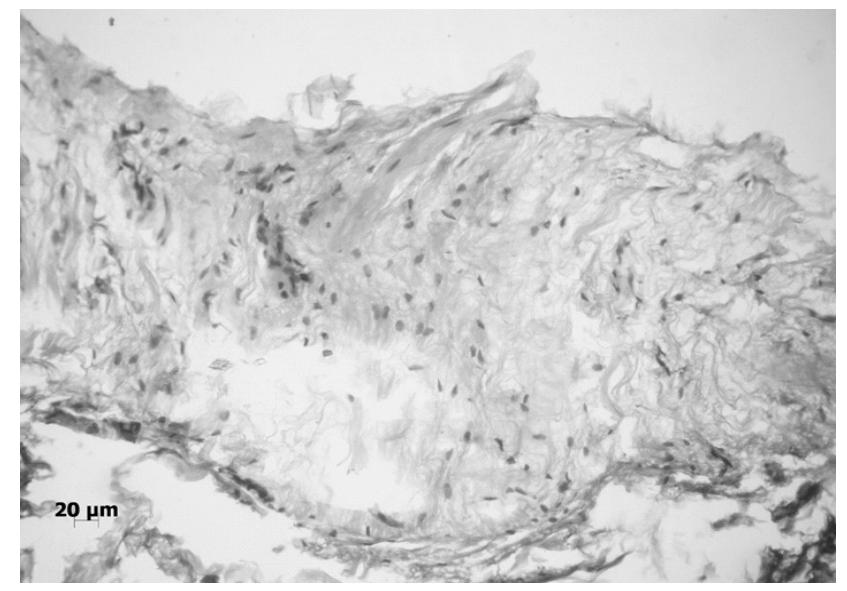

Рис. 5. Край диафрагмы. Неоформленная бесструктурная соединительная ткань с обширными очагами лизиса и низкой плотностью клеток. Гематоксилин и эозин. Ув. 200.

Сохраняются участки плотной соединительной ткани с выраженными деструктивными и дистрофическими нарушениями. Между разрозненными пучками коллагеновых волокон, имеющих извитой вид, располагаются обширные отечные полости и очаги гиалиноза (рис. 6), что свидетельствует о распаде белков, как синтезированных клетками, так и входящих в состав межклеточного вещества.

Плотность кровеносных сосудов низкая, обнаруживаются кровеносные сосуды капиллярного типа, а также венулы и единичные артерии мышечного типа. Особенностью сосудистого русла края диафрагмы в условиях грыжеобразования является присутствие венозного переполнения, стаз капилляров, нарушение стенок артериол (рис. 7).

При поляризационно-оптическом исследовании пучков коллагеновых волокон сухожильной части диафрагмы, её ножек и грыжевого мешка выявлено, что они имеют различную степень зрелости и

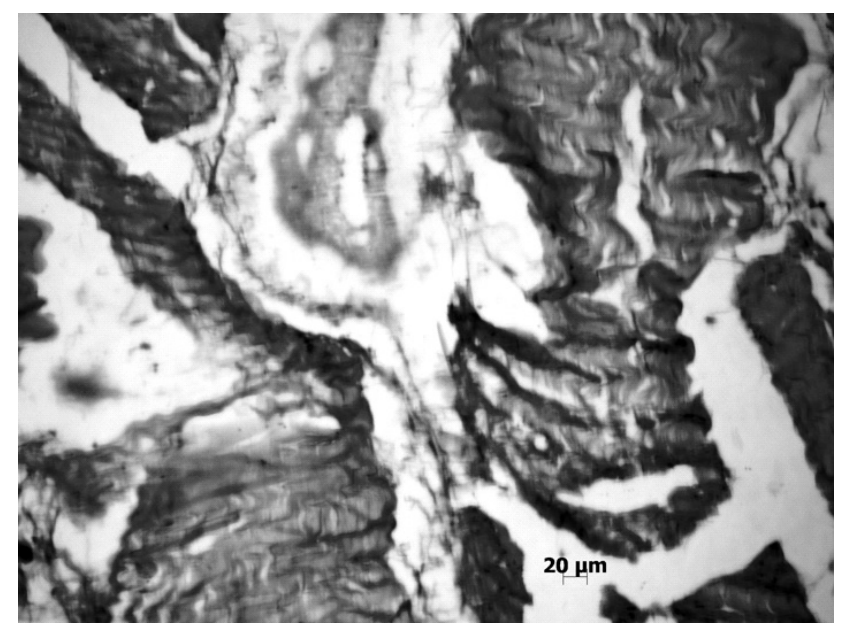

Рис. 6. Край диафрагмы. Зигзагообразные пучки неупорядоченно расположенных коллагеновых волокон. Гиалиноз. Гематоксилин и эозин. Ув. 200.

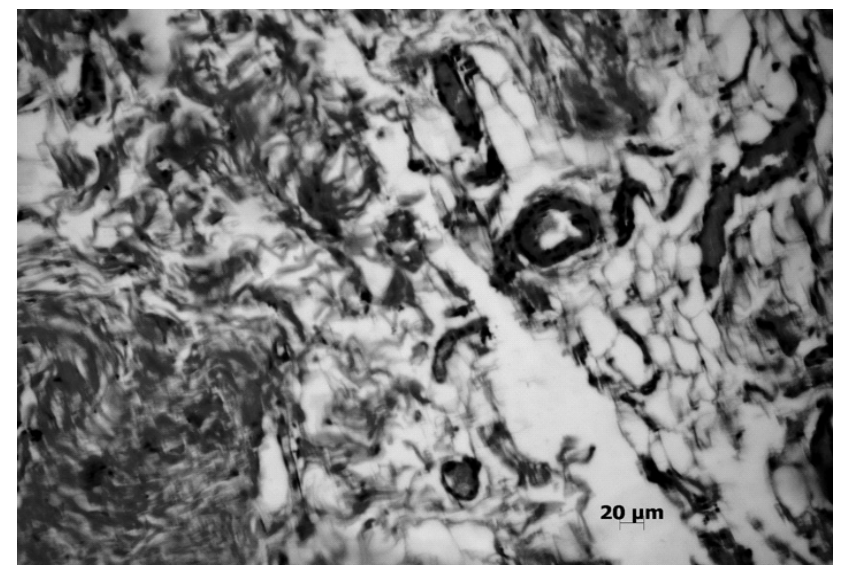

Рис. 7. Край диафрагмы. Рыхлая соединительная и жировая ткани. Сосуды, переполненные кровью. Венозный застой. Гематоксилин и эозин. Ув. 200.

ориентационной упорядоченности. В основном преобладают неупорядоченно расположенные пучки коллагеновых волокон, имеющих желтое или слабо зеленое свечение, зрелые пучки - красного свечения - занимают небольшие территории (рис. 8, 9).

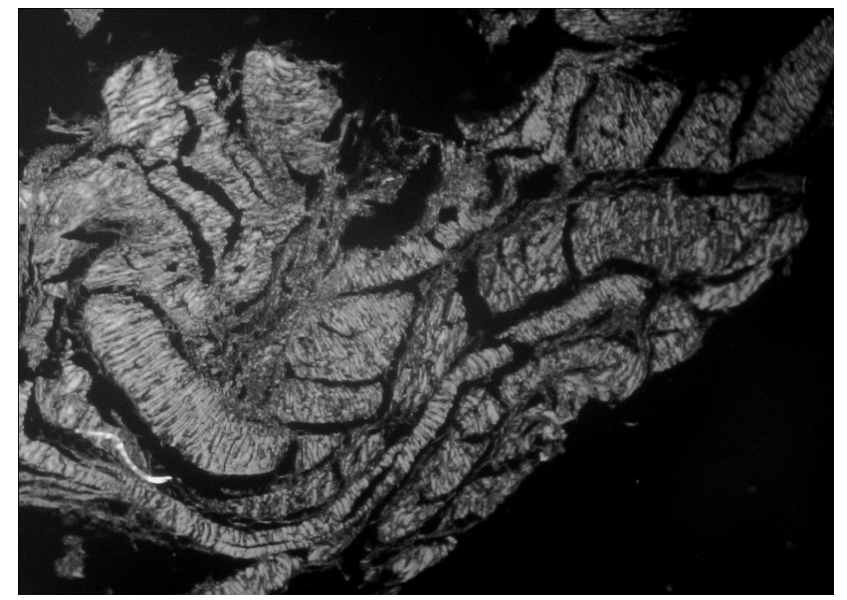

Рис. 8. Коллагеновые волокна сухожильных тканей ножки диафрагмы. Поляризационный свет. Пикросириус красный. Polmy-А. Ув. 80.

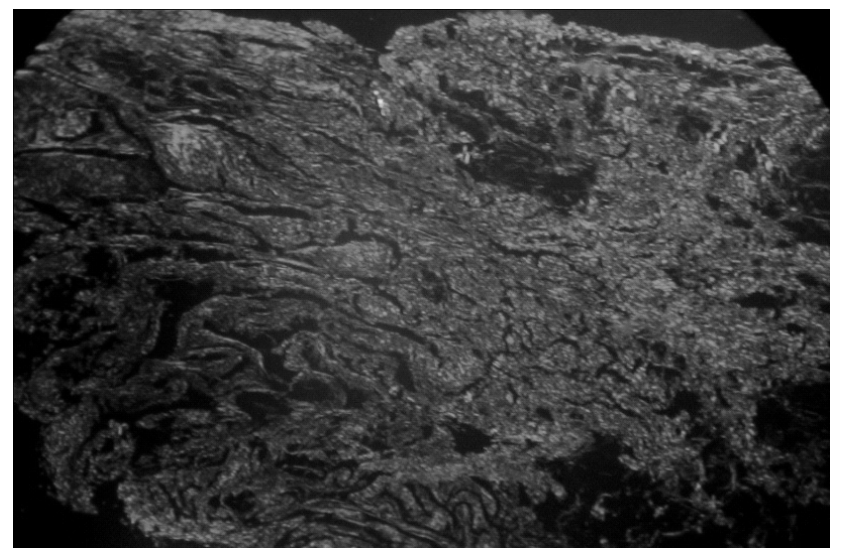

Рис. 9. Коллагеновые волокна грыжевого мешка. Поляризационный свет. Пикросириус красный. Polmy-A. Ув. 80. 
Выводы. В ножках и сухожильной части диафрагмы у больных с грыжами пищеводного отверстия диафрагмы имеют место выраженные структурные нарушения, заключающиеся в гиалинизации сухожильной ткани, неупорядоченном расположении пучков коллагеновых волокон, дегенерации мышечной ткани, наличии лимфогистиоцитарных инфильт-

\section{СПИСОК ЛИТЕРАТУРЫ}

1. Василенко В. Х. Грыжи пищеводного отверстия диафрагмы / В. Х. Василенко, А. Л. Гребенев. - М. : Медицина, 1978. $-213 \mathrm{c}$.

2. Ройтберг Г. Е. Внутренние болезни. Система органов пищеварения : учебн. пособие / Г. Е. Ройтберг, А. В. Струтынский. - М. : МЕДпрессинформ, 2007. - 560 с.

3. Саркисов Д. С. Микроскопическая техника : руководство / Д. С. Саркисов, Д. С. Перов. - М. : Медицина, 1996. - 544 с. 4. Чибисов А. Л. Патогенетические аспекты послеоперационных вентральных грыж / А. Л. Чибисов, Р. В. Бондарев // Український медичний альманах. - 2008. - Т. 11, № 5. - С. 197-199. 5. Histological findings of the internal inguinal ring in patients having indirect inguinal hernia / G. Amato, L. Marasa, T. Sciacchitano [et al.] Springer-Verlag. - 2009. ратов, венозном застое. Применение различных видов аутопластик на фоне установленных морфологических изменений может способствовать развитию рецидива ГПОД. При грыжах II-III степени, когда изменения в мышечной и сухожильной ткани значительно выражены, обоснованным будет применение сетчатых протезов.

6. Klinge U. Are collagens the culprits in the development of incisional and inguinal hernia disease? / U. Klinge, M. Binnebцsel, P. R. Mertens // Hernia. - 2006. - Vol. 10, № 6. - P. 472-477.

7. Li X. J. "Monitoring homovanillic acid and vanillylmandelic acid in human urine by capillary electrophoresis with electrochemical detection" / X. J. Li, W. Jin // Chin. Chem. Lett. 2002. - Vol. 13. - P. 874-876.

8. Biochemical study of collagen in adult groin hernias / A. Pans, A. Albert, C. M. Lapiure, B. Nusgens // J. Surg. Res. 2001. Vol. - 95. - № 2. - P. 107-113.

9. Constantine V. S. Selective staining of human dermal collagen II. The use of picrosirius red F3BA with polarization microscopy / V. S. Constantine, R. W. Mowry // J. Invest. Derm. - 50. Vol. 414. - 1968.

Получено 25.01.13 